\title{
Liberation Psychology: From Latin America to Aotearoa/New Zealand
}

SEINI O'CONNOR, BENJAMIN A. TILYARD AND TACIANO L. MILFONT ${ }^{1}$

\section{Introduction}

Liberation psychology is as much a social movement as a psychological sub-discipline. It focuses on enabling oppressed groups (in particular, those oppressed through colonization) to engage in self-reflection, selftransformation, and ultimately, true psychological and cultural liberation - which in turn liberates society as a whole.

The roots of liberation psychology lie in Latin America, where the movement was inspired by the writings of Paulo Freire in Brazil and developed by Ignacio Martín-Baró in El Salvador. ${ }^{2}$ However, the conditions that inspired the growth of liberation psychology - in particular, oppression and colonial hegemony - are, of course, not unique to Latin America. Such conditions are experienced in many countries, including Aotearoa/New Zealand. In response, researchers around the world have begun exploring how liberation psychology may help address the problems associated with these oppressive colonial legacies. ${ }^{3}$

In Aotearoa/New Zealand, as in Latin America, historical colonialism has left a legacy of imbalance in the political power, educational achievements, and socio-economic conditions of minority groups. In both regional contexts, the burden of such inequality falls predominantly on indigenous peoples. Notably, indigenous scholars in Aotearoa/New Zealand have done much to redress power imbalances and promote positive developments within their communities by developing, and working within, culturally appropriate frameworks that diverge from the 'mainstream' within their various disciplines (which include, though are not limited to, psychology). The process of enquiry that these scholars have followed shares many similarities with that of liberation psychology. However, liberation psychology is a littleknown discipline in Aotearoa/New Zealand, where the Western, empirical psychological traditions that emerged from North America still dominate.

We propose that psychologists throughout Aotearoa/New Zealand have much to gain from becoming more familiar with the principles of liberation psychology. Non-indigenous psychologists, in particular, could benefit by broadening their focus beyond the limited scope of the empirical practices within which the majority currently work. This broadened focus should 
not supplant, but rather enhance and complement existing indigenous research methodologies, and provide a more comprehensive framework for transforming mainstream psychological practice and research into a form more appropriate for, and representative of, disempowered communities.

As a first step towards increasing familiarity with liberation psychology, in this paper we set out to provide a 'gentle' introduction, which we hope will inspire further investigation. We begin by introducing liberation psychology as a general approach, explaining its underlying rationale and assumptions, its processes, and its vision. We then highlight particular issues the movement has focused on in Latin America, and note where other countries may face similar issues. Having established this background, we turn our focus to potential applications and implications for liberation psychology in Aotearoa/ New Zealand. In particular, we note the role that liberation psychology can play in developing community dialogues that adequately recognize the legitimate voice of marginalized groups. Finally, we draw out key conclusions from our review, and make suggestions for future research and practice.

\section{Liberation psychology: foundations and beliefs}

Liberation psychology has its origins in liberation theology - a movement that gained prominence through the Roman Catholic Church in Latin America in the 1950s and 60s, and which aimed to fulfill Christian ideals of justice by bringing equality and recognition to the poor and oppressed. This movement inspired Ignacio Martín-Baró, a Spanish-born Jesuit priest with a $\mathrm{PhD}$ in Social Psychology from the University of Chicago, to call for similar liberation in psychology. ${ }^{4}$

Martín-Baró argued that, by and large, psychology had only served the interests and requirements of dominant groups in society, and that the discipline was fundamentally unable to criticize the very system it supported. He proposed that the discipline needed to liberate itself from its own chains, and develop: (1) a new horizon, which would shift the focus of attention away from itself and its scientific status in order to more effectively address the prevailing problems of majority (but marginalized) populations; (2) a new epistemology, which would encourage acknowledging and locating truth within marginalized populations in order to adequately recognize the reality of their suffering, aspirations, and struggles; ${ }^{5}$ and (3) a new praxis, which would work to actively transform the realities of marginalized individuals and societies throughout Latin America through informed practice.

Although Martín-Baró drew from theology for a guiding framework, it is important to note that liberation psychology holds a secular, psychological framework at its core. This framework is modeled on psychological conceptions of social identity, self-esteem, and well-being - but in a manner 
that is emphatically different from that employed in 'mainstream' empirical social psychology. From the outset, Martín-Baró and other liberation psychologists sought to distance themselves from empirical social psychology, chiefly because they viewed it as having fundamental limitations. ${ }^{6}$

Three such limitations were particularly salient in Latin America. Firstly, the theories emerging from empirical psychology were culturally limited, having been drawn from observations of select Western populations using Western investigative techniques. ${ }^{7}$ Key proponents of liberation psychology argued that these theories were thus unsuitable for application in Latin American countries with distinct cultural traditions and historical legacies of colonial oppression. Secondly, empirical psychologists failed to acknowledge the inherent cultural-specificity and hence subjectivity of their theories, thus denying the moral implications of applying their frameworks onto non-Western samples. As a result, the voice and viewpoints of marginalized Latin American communities were being rendered void by the perpetuation of the Western cultural lens. Finally - and perhaps most importantly from a community perspective - empirical psychology was largely theory-focused, and produced little practical knowledge of use to marginalized communities. Thus, in Latin American countries facing enormous human and economic development challenges, purely theoretical psychology appeared to be of little value.

In response to these inherent limitations of mainstream empirical psychology, liberation psychology seeks to redefine fundamental notions of society and its members in order to create space for new, more inclusive psychological dialogues, research and practice. To this end, liberation psychology makes two key assertions. The first assertion is that prevailing circumstances and belief systems do not represent a natural order, but rather an order imposed by a particular group or culture. ${ }^{8}$ Psychologists must view power relations in historical contexts and must become aware that oppression may be entrenched through 'invisible' and deep-seated societal belief systems (often internalized even within oppressed groups) that rule out of concealment. Furthermore, having gained this contextual awareness, psychologists must then adapt their own research and practice to be contextually-sensitive, and not assume psychological universality. Without such awareness and adaptation, psychologists may inadvertently perpetuate patterns of oppression and institutionalized racism - for example, by pursuing mental health intervention strategies that are inconsistent with the cultural beliefs, values, norms, and traditional practices of marginalized groups. ${ }^{9}$

The second assertion is that all people have capacity for empowerment: the oppressed or marginalized are not liberated by others, but through their own initiative. Liberation is a painstaking and ongoing construction, rather than a gift or static end-state; and as such it must (and can only) be driven 
by those in need of liberation. ${ }^{10}$ The role of the psychologist, then, is not to be a liberator, but to facilitate the processes of reflection and transformation as a means to liberation.

\section{The liberation process}

Liberation is in many respects the slow reversal or unraveling of oppression. Both liberation and oppression are historical processes; and both make their effects more apparent over time. ${ }^{11}$ Proponents of liberation psychology envisage liberation taking place through a multi-step process of psychological and socio-cultural development. This process begins with oppressed peoples becoming aware of how inequitable and detrimental their social conditions are, of the way their conditions relate to social structures and relationships, and of their capacity to change these conditions, a process Paulo Freire described as conscientization.

This new consciousness sparks the motivation to more closely analyze and begin to question the culturally-biased assumptions in society's 'truths' or habitual ways of thinking (through processes of problematization and denaturalization). Then, through a process of de-alienation (a concept adopted from Marxist thought), oppressed peoples begin to recognize the damaging effects that society's so-called truths have had on them, and see these truths in their social and historical context. Finally, this critical analysis and new understanding provides the basis for forming a new reality: through a process of de-ideologization oppressed peoples begin to develop alternative viewpoints and a new dialogue, and to act in new ways.

\section{The liberation vision}

Liberation can have important implications for oppressed individuals whose affect, behaviour, and cognitions are (positively) transformed and given new legitimacy through the liberation process. ${ }^{12}$ Collectively, these transformations can also build strength in entire communities, thus empowering groups that have historically been oppressed.

Perhaps less evidently, liberation can also have positive implications for dominant groups, even those whose dominance (and all its associated benefits) fades as the previously oppressed become newly empowered. All members of society stand to benefit in the long term if all social groups are afforded better conditions and more equal status. Thus, liberation is not solely about transferring power from one group to another, but about reaching a superior societal equilibrium in which power is more equitably distributed.

To achieve these significant social outcomes, liberation psychology is necessarily action-driven, rather than theory-based. Indeed, Martín-Baró argued that developing a liberation psychology is first and fundamentally a 
practical task. To the extent that theories play a part, they do so alongside practice in a mutually interdependent process, or praxis. Liberation psychology emphasizes that psychologists should use practical, observational approaches to identify social needs, and then apply and continually adapt appropriate theorization and practice to address those needs in full. ${ }^{13}$

\section{Liberation in practice}

Three key areas of practice have emerged from liberation psychology's action-focused approach: (1) social analysis from a liberated perspective; (2) the use of social psychology to understand and identify potential ways to meet community-specific needs; and (3) the development of liberating, therapeutic programmes with and for oppressed peoples. ${ }^{14}$

Liberated social analysis involves analyzing the 'social climate' of a given group or country in order to better understand the dynamics of disadvantage, and the perspectives of different societal groups. Specific analytical projects include assessing child development within contexts of institutionalized violence, identifying the social impacts of urbanization, and analyzing social and political movements in terms of their underlying historical and social processes.

Community-focused social psychology involves identifying areas of concern in the social support systems that are fundamental to community well-being. Psychologists work together with communities to better understand community challenges such as economic disadvantage, inadequate education, and low access to health services. They then collaborate with communities to develop a vision of how each problem may potentially be addressed, both from a broader policy perspective and through communitylevel initiatives.

Finally, liberation 'therapy' involves not only addressing individual suffering, but also acknowledging that its root cause may be societal. Rather than treating suffering in a private and individualized manner, liberation psychologists may work within or alongside communities to facilitate appropriate forms of public expression or social healing processes. For example, they may be involved in community initiatives to revive collective memory as a means to combat the trauma of having their experiences denied by officials. Some psychologists may also work with communitysanctioned lawyers and human rights activists to help prosecute perpetrators of oppression, thereby seeking a remedy to individual suffering at the societal level.

As we explain in the following sections, over recent decades these areas of practice have emerged and flourished not only throughout Latin America, but also increasingly in other countries with a shared context of colonialism and oppression. 


\section{The liberation movement in Latin America}

The application of liberation psychology in Latin America is best understood in light of the region's history. Although a full exploration of this history is beyond the scope of this paper, it is worth briefly considering the pattern of colonization that has taken place over several centuries.

The most damaging colonial influence essentially began when explorations by the Spanish and Portuguese in the fifteenth century led to both countries laying claims for American territory. Following the Treaty of Tordesillas established in 1494, Spain formed its empire in the central and southern parts of the Americas, focusing on the exploitation of human and material resources, including exploitation of large and settled societies (for example, Aztec, Inca and Maya) and large concentrations of silver and gold. In contrast, Portugal focused on Brazil, reaching its coast in April 1500. Like the Spanish, the Portuguese also exploited human resources: first, the native populations (mainly from the Tupi-Guarani and Tapuia language groups), and later, African slaves.

As a consequence of this empire building, for several centuries the wealth accumulated within Latin America was stripped by European colonizers and claimed as their own. Indeed, from the discovery of the New World to the current period, Latin American resources have been transformed into European or North American profits with no regard for the welfare of the land and economy from which they were stolen. ${ }^{15}$

These historical circumstances have led to significant social and psychological disadvantages for marginalized communities throughout Latin America. Although many of these communities have sizeable populations, they have minimal power; instead, power is held by a ruling minority of generally lighter-skinned peoples. ${ }^{16}$ In addition, the marginalized are frequently disadvantaged in terms of resource allocation and access to services, resulting in poor educational, health, and economic outcomes compared to their socially-favoured co-nationals. Furthermore (and often as a result of such inequalities) many Latin American countries have been characterized by ongoing conflict and violence. This has disrupted social order and propagated fear and uncertainty, causing distress and unrest for both communities and individuals.

Liberation psychology emerged as a response to these social conditions, presenting an empowering approach to addressing significant social needs. The movement was embraced and further developed as a form of intellectual and political resistance to the unwavering dominance of both local elites, ${ }^{17}$ and of North American mainstream science and political influence. ${ }^{18}$ Of course, true to its spirit, liberation psychology presented more than solely ideological resistance; crucially, it also involved the development of new, 
practical, and culturally-sensitive approaches in psychological research and practice. ${ }^{19}$ These areas of research and practice have spanned the breadth of defending human rights, encouraging community organization, combating gender discrimination, and empowering citizens to be more involved in their communities. ${ }^{20}$

Perhaps one of the most significant practice areas of liberation psychology in Latin America has been in therapeutic programmes. Guatemala presents an interesting example of how such programmes have been used to understand and treat psychological distress, and how it differs from a mainstream approach. Ethnic Mayans in Guatemala suffered years of brutal civil war and genocide, leading to significant trauma and distress for individuals and social groups. ${ }^{21}$ From a dominant, Western perspective, many Mayans could potentially be diagnosed and treated for post-traumatic stress disorder. However, Comas-Díaz et al. propose that such diagnosis and treatment would grossly ignore the cultural and historical contexts of the trauma, and fail to provide long-term, sustainable remedies. ${ }^{22}$ In contrast, a liberation psychology approach - acknowledging both past and present injustices, and identifying wounds inflicted by these injustices in culturally-appropriate terms - appears to have proved more effective. Successful examples of such work cited by Comas-Díaz et al. include large-scale national projects (for example, documenting and thereby legitimizing local experiences of the civil war), and more participatory, action-based research with communities (for example, collaboration with local leaders to develop culturally appropriate techniques for healing).

Another important way in which liberation psychology has been applied in Latin America has been in the combination of social analysis and liberation therapy to enhance identity and self-esteem. For example, Comas-Díaz et al. point to Puerto Rico, a country characterized by a lack of clear national identity and covert racism (where greater status is accorded to those who are perceived as 'more white', regardless of how they racially identify themselves). In such a context, issues of identity and esteem are very difficult to successfully tackle on an individual basis. However, Comas-Díaz et al. state that local psychologists have successfully used 'emancipatory literature' (which assists readers in conscientization by identifying how external, colonial forces are responsible for feelings of uncertainty and inadequacy) as part of a therapeutic process for individuals and their communities.

These examples highlight how liberation psychology in Latin America has focussed on pressing social issues, with the aim of enhancing both individual and community well-being. The approach has been contextually-sensitive, and has focussed on empowering historically marginalized communities through a process of revealing oppressive beliefs and systems, deconstructing them, and rebuilding lives through new and culturally-appropriate narratives. 


\section{Oppression and liberation in other cultural contexts}

Beyond Latin America, communities in both the majority and minority worlds ${ }^{23}$ face similar issues of marginalization and oppression - particularly indigenous communities. ${ }^{24} \mathrm{~A}$ recent model has even outlined a unique duo of ideologies that is arguably common to all post-colonial nations as a result of similar socio-structural conditions..$^{25}$

Of course, there are also important distinctions between indigenous communities within and outside Latin America. One area of difference, in particular, is in the relative size of the indigenous and non-indigenous populations. Many of the marginalized communities in Latin America represent a majority of the national population. As a result, the damaging effects of the marginalization of these communities are evident not only in the outcomes for the ethnic groups involved, but also in the development outcomes of the country as a whole (for example, low national literacy rates and life expectancies). By contrast, in many other countries, marginalized groups are minorities, and their outcomes may not be reflected in countrylevel statistics. Thus, educational, health, and economic country statistics that are favourable by international standards may conceal much poorer outcomes in marginalized communities.

However, the percentage of the population that is marginalized is not necessarily an indicator of relative 'need' for liberation (although the population size may in some situations play a role in achieving liberating change, through sheer popular momentum). Arguably, any society that is characterized by historical inequalities between groups is in need of, and would benefit from, a more balanced distribution of power and more equitable social outcomes. ${ }^{26}$ Most societies have dominant paradigms - psychological or otherwise - that serve to reinforce institutionalized oppression. ${ }^{27}$ Likewise, most societies have underprivileged and marginalized minorities that are similar to those groups who have been the focus of liberation psychology in Latin America. ${ }^{28}$

These conditions suggest that many countries could benefit from liberation psychology - and indeed, some are now attempting to do so. There is an emerging willingness to discuss and challenge dominant psychological paradigms when working with peoples from different cultural backgrounds, and an awareness that these paradigms are usually developed in the minority world and thus do not necessarily reflect the knowledge or needs of marginalized groups. ${ }^{29}$ As a specific example, Duran et al. explain that some North American psychologists have successfully used a liberation psychology approach in developing new, more effective and culturally sensitive ways of conducting therapy with indigenous populations. ${ }^{30}$ They also claim that the health providers' increasing awareness of the importance of historical trauma 
on current well-being is helping to break down patterns of institutionalized racism throughout the North American health system.

At a broader, community level, liberation psychology can also be seen at work in the development of institutions such as the Truth and Reconciliation Commission in South Africa. This Commission's mandate was to bring the stories of victims of apartheid violence into the public arena, and to publicly hold the perpetrators of such violence to account. This process legitimized the experiences of the oppressed, and helped South Africans to develop a shared, more inclusive national view of history that fully acknowledges past transgressions but also allows space for the reconciliation and rebuilding of both individual and national identity. ${ }^{31} \mathrm{~A}$ somewhat similar process is being followed with the Aboriginal and Torres Strait Islander Healing Foundation in Australia, which has been initiated in the space created by the official 'Apology to Australia's Indigenous Peoples' issued by the Australian Government in 2008. ${ }^{32}$

Principles of liberation psychology are also evident in the work of psychologists who have developed new research techniques. In particular, indigenous scholars have strongly promoted the use of less empirical and quantitative methods in favour of qualitative models. For example, researchers in the Philippines have proposed that local studies begin with a pakapakapa approach (involving, literally, 'groping' for ideas) to collaboratively define research questions based on local needs and issues. ${ }^{33}$ Once these questions have been defined, researchers can undertake their investigation using processes such as pagtatanong-tanong (discussing, asking questions), in which both researcher and the researched group are equally empowered to drive dialogue. In this type of research process, the focus is still (as in 'Western' methods) on investigative rigour, but this rigour is achieved through a more culturally-appropriate process. The end result is better for the communities involved in research, providing useful information and relevant applications.

\section{Applying liberation psychology approaches in Aotearoa/New Zealand}

The international examples of liberation psychology described above are equally relevant to Aotearoa/New Zealand, both in directly applied contexts and in academic research methodologies involving community interactions. In Aotearoa/New Zealand (as in many countries in Latin America, and beyond) colonization has led to the oppression and denial of Māori identities, social structures, livelihoods, and customs. This oppression did not only occur in the past; it continues today through dialogue that calls on ideals of equality and reason to justify the practice of ignoring entrenched inequalities. ${ }^{34}$ However, Aotearoa/New Zealand's story differs somewhat from that of many countries 
where indigenous groups have been forcefully marginalized. In particular, the country's Te Tiriti o Waitangi (Treaty of Waitangi), which legally signals the government's responsibility to respect Māori sovereignty in an ongoing national partnership between Māori and Pākehā (non-Māori New Zealanders, principally of European descent), creates an avenue for addressing ongoing colonialism by providing a "centrepiece of a bicultural narrative' ${ }^{35}$ through which the government's transgressions of Treaty principles can be properly called to account. ${ }^{36}$ Within this context, Māori leaders and scholars have done much to develop and promote an indigenously appropriate methodology for social science research and practice (kaupapa Māori) and arguably have reclaimed greater ground than other indigenous groups subject to similar colonial processes.

We propose that liberation psychology methodologies present a complement to the advances already made by Māori in reclaiming their power and position as the indigenous people of Aotearoa/New Zealand. As in kaupapa Māori, culturally appropriate methodologies are particularly important within liberation psychology, and apply across the movement's three distinct areas of application, as well as in research. Below, we discuss how each area of application is relevant to Aotearoa/New Zealand.

\section{Liberated social analysis: recognizing impacts of past injustice on current identity}

Although essentially an analytical rather than an applied task, social analysis underpins the development of important policies and practices, and thus is a key area in which psychological knowledge can be applied. By focusing on identifying average trends, such analysis often captures only the needs and views of the majority, rather than being fully representative of society. Thus, undertaking social analysis from a liberated perspective has the ultimate goal of illuminating the feelings and thoughts of individuals from all communities.$^{37}$ By bringing these thoughts out into the open, liberated social analysis not only greatly enhances public awareness of past and current oppression, but also opens up a forum within which the oppressed are able to make their voices heard.

In the context of Aotearoa/New Zealand, a liberated perspective to social analysis would involve overcoming the desire to deny the past and present existence of racism and colonial influence. Research suggests that prolonged denial of racism may have adverse long-term effects on the oppressed group, particularly because it can lead to a denial of individual and collective identity. ${ }^{38}$ Thus, it is essential for social justice and collective well-being that past and present oppression is acknowledged rather than glossed over in the hope of focusing on a more equitable future. Without such recognition, oppressed groups may in effect internalize racism, blaming themselves 
for their current position and evoking a sense of guilt and shame that is reinforced through the imposition of ill-fitting social identities by a more dominant culture.

Liberation psychology suggests that in order to acknowledge racism and inequity, social analysts and national leaders should be explicit in identifying the injustices surrounding Aotearoa/New Zealand's Te Tiriti o Waitangi. Only when such injustices are accurately acknowledged within official historical recollections can both Pākehā and Māori maintain individual and collective identities. By opening a dialogue in which the voices of both groups can be equitably recognized, historical and present-day injustice and inequalities can be fully acknowledged. Liberated social analysis can assist both Māori and Pākehā in finding a means of redress and in moving forward in a unified and mutually beneficial way.

Of course, analysts and leaders will need to be sensitive in their approach to including Māori voices in social analyses. In particular, in line with the liberation psychology view that cultural and contextual factors should always be recognized, analysts and leaders should take care not to assume that one Māori voice stands for all; different iwi (tribes), and Māori with different degrees of integration with Pākehā and other cultural groups, have underlying social, cultural and psychological differences, and need to be represented in a way that does not attempt to homogenize their experiences. ${ }^{39}$ This suggests that fresh analysis is important for the construction of appropriate broad frameworks not only at the national level, but also at the community level.

\section{Community-focused social psychology: developing policies that meet needs}

A second area in which liberation psychology can be applied in the Aotearoa/ New Zealand context is in the use of social psychology to identify potential ways to meet community-specific needs. Whereas liberated social analysis can help in providing a broad, national framework for developing a more equitable and pluralistic social identity, community-focused psychology helps in developing more specific, local frameworks for addressing relevant community concerns. A liberation psychology view suggests that these local frameworks or policies will only be effective if they incorporate input from individuals and communities who will be most affected by (and stand to benefit most from) their implementation. Thus, local policy development must be a truly consultative process, informed by a robust understanding of the social history and current dynamics within the community.

To ensure broad participation in consultation processes, policy makers can adopt affirmative action policies that promote the involvement of marginalized groups. ${ }^{40}$ Increased participation by the marginalized can 
foster inter-group trust, ultimately serving to create inter-group harmony and positive relationships both at an individual and collective level. Increased participation is also essential for ensuring appropriate representation and shaping of services at an institutional level; for example, Durie points to the need to increase Māori representation amongst health service providers (potentially with new qualifications to recognize essential cultural skills that are not currently deemed to be 'qualifications'), and increase Māori autonomy and control over the planning and delivery of health services. ${ }^{41}$ Such initiatives may be used in order to improve Māori health outcomes, as measured by indigenously appropriate indicators.

These inclusive, affirmative action approaches challenge the legitimacy of arguments for 'one country, one people' policies. Such policies deny the value of ethnic-group identification and, by employing Western frameworks for identifying equal needs, attempt to offer equal resources to all. Although the notion of a collective identity has appeal, in reality, 'one people' policies do not achieve equitable outcomes or reflect real needs. ${ }^{42}$ In contrast, policies that recognize inequity in the current system, that are shaped through a more participatory approach, and that empower minority groups by giving them more autonomy - in other words, policies that align with communityfocused, liberation psychology ideals - have been, at least partially, successful in achieving better health and education outcomes for such communities in Aotearoa/New Zealand. ${ }^{43}$

\section{Therapeutic programs: working to improve mental health}

A third key area in which liberation psychology can be applied is in therapeutic programmes. Such application can be made in methodologies that identify where psychological harm has been caused through complex and historical approaches. Such techniques take into account not only individuals (and individual problems) but also their broader family, community, and country contexts. ${ }^{44}$ Liberation therapy emphasizes the need to make past and present suffering a shared burden, rather than one that is secret.

Scholars following a kaupapa Māori methodology have developed some instructive texts on similar therapeutic approaches. For example, Durie highlights the importance of what are essentially liberated therapeutic approaches in helping Māori affected by mental health problems which, he suggests, are among the most serious health issues affecting Māori in modern times. ${ }^{45}$ A key element of effective treatment, Durie argues, lies in assisting Māori to develop a secure sense of identity through promoting te ao Māori (the Māori world) in their lives; in particular, through language, family networks and customary land.

Such a holistic and culturally-appropriate view of health is also captured in the Te Whare Tapa Whā model. ${ }^{46}$ This model conceptualizes holistic health 
as a 'house' supported by the walls of tinana (physical), wairua (spiritual), hinengaro (emotional), and whānau (social) health, all of which are of particular significance to Māori, and are intrinsically linked in a way that Western (Pākehā) conceptions often fail to appreciate. As Rochford argues, the adoption of this more holistic model provides space for personal and community development within a culturally enriching context, thus helping to reverse the negative and oppressive effects of colonization on Māori identity. ${ }^{47}$

\section{Liberation psychology in research methodologies}

Although the focus of liberation psychology is primarily on practice particularly in the three areas identified above - we believe it also has relevance for those working in the field of academic research. For example, Māori scholars such as Linda Tuhiwai Smith have long called for the decolonization of research in Aotearoa/New Zealand, by means of both deconstruction (of oppressive assumptions, narratives, and structures), and re-construction (ultimately, of self-determination). ${ }^{48}$ These foci resonate with those of liberation psychology in Latin America and suggest that there are more appropriate ways of working with minority groups, such as Māori, in Aotearoa/New Zealand.

\section{Deconstruction: identifying dominant ideologies and overcoming barriers}

As Smith elucidates, all research methodologies are underscored by a defining ideology - that is, a way of knowing and understanding the world. Often, this ideology is left implicit, and researchers fail to acknowledge the cultural viewpoint that influences their choice of research topic, the research questions they propose, and the methods they adopt for exploring these questions. She proposes that to undertake truly meaningful and equitable research involving Māori, researchers must begin by stripping their work back to its underlying ideologies. In place of Western perspectives, they should strive to adopt a kaupapa that reflects a Māori understanding of the world, and of the way in which knowledge about the world can be validly obtained. This in turn will influence the focus of research and the content of research findings, pointing researchers towards the areas of greatest importance for understanding Māori reality.

Beyond ideology, research in Aotearoa/New Zealand (and indeed elsewhere) is also heavily influenced by the availability of funding. Where national priority is given to areas that can be shown to have beneficial economic impacts, research into areas of great cultural importance may be marginalized. Barriers to accessing funding - including the application process itself - may serve to entrench inequities and further marginalize 
research by minority groups into areas that may be of most benefit to these groups. Thus, making research funding less subject to political control and more democratic is a key priority for decolonizing efforts in Aotearoa/ New Zealand.

\section{Reconstruction: adopting new methods}

Having acknowledged the (implicit) forces that serve to undermine indigenous research in Aotearoa/New Zealand, Smith suggests how research could be undertaken in a more decolonized way. This need not involve discarding useful psychological practices; often, enhancing research involves using the 'same' techniques, but with a different underlying focus. Thus, researchers may approach an interview with different intentions: solely to 'extract' words or knowledge from the interviewee; to record the whole interview experience, analyzing silences, body language, and a range of linguistic features alongside the content of what is spoken; or even to look underneath the 'talk' for deeper meanings and themes. Each of these approaches presents a different conception of which parts of the interview convey knowledge and which are peripheral features. Furthermore, the differences between such approaches can serve to illustrate how data can be analyzed from a decolonized perspective.

For research focusing on Māori, Smith emphasizes the use of tikanga whakaaro, or Māori values and research ethics. These include following methodological principles such as aroha ki te tangata (showing respect for people), kanohi kitea (being a 'seen face' by meeting with people personally, and being involved in the community), and manaaki ki te tangata (hosting and showing generosity), among others. These suggest a more holistic focus than simple 'knowledge extraction'; rather, knowledge is sought from multiple sources, and shared on a more equitable basis. Because of the skills required for such seeking and sharing, such research may best be created and conducted by Māori researchers, with the aim of specifically benefiting Māori. ${ }^{49}$

\section{Implications of adopting liberation psychology in Aotearoa/New Zealand}

Aotearoa/New Zealand is becoming increasingly multicultural, suggesting that now, more than ever, the country needs to adopt more inclusive perspectives, policies and practices. As a first step, these need to address ongoing inequities in the bicultural partnership between Pākehā and Māori - a partnership that will ideally form a firm foundation for our evolving society. Research has shown that biculturalism is automatically and non-consciously supported by both Pākehā and Māori, but that this support is more evident for symbolic policies and praxis related to biculturalism rather than to specific policies 
aimed at improving the equality of resource distribution. ${ }^{50}$ Future actions should thus focus on resource-specific policies. ${ }^{51}$

As the preceding discussion has demonstrated, liberation psychology offers a useful framework for developing such policies and their related perspectives and practices. Importantly, it does so not by imposing an 'outside' ideology, but by suggesting how resources and voices from the 'inside' can be mobilized to increase participation and the subsequent liberation of marginalized communities. Thus, in drawing lessons from the Latin American experience (and experience with liberation psychology elsewhere in the world), the intention of this paper is not to propose that psychology in Aotearoa/New Zealand should follow in exactly the same direction, but rather that the ideals of liberation psychology should be more widely recognized, and interwoven with the work of local Māori and Pākehā psychologists in the development of an authentic and contextually-appropriate approach.

The exact shape of such an approach requires further development and is beyond the scope of this introductory paper. However, there are already some indications of what the adoption of liberation psychology may imply for future psychological practice in Aotearoa/New Zealand. One such area of future development may be in the strengthening of international connections between Māori and other indigenous communities, united by a shared liberation agenda. Already, several international indigenous associations and annual conferences have been established to provide a global network for the discussion of local issues. Examples include the World Indigenous People's Conference on Education held in Melbourne in 2008, the International Indigenous Conference on Traditional Knowledge scheduled for Auckland in June 2010, the International Indigenous Women's Forum (http://indigenouswomensforum.org/), and AlterNative, an international journal of Indigenous Peoples. Bilateral and multilateral partnerships and exchanges between indigenous scholars may serve to strengthen and expand these existing connections.

Another area showing much potential for future development is in the relationship between research and policy development. Liberation psychology emphasizes the importance not only of developing knowledge through more inclusive methodologies (in particular, those that challenge 'mainstream' or entrenched, Western orientations), but also of applying this knowledge for the benefit of the community, in the widest sense. This suggests that both policy and research should ideally be shaped by a decolonized ideology or kaupapa that poses appropriate questions, and finds meaningful answers. It also suggests that policy-making and research should be mutually informing, and that both should seek input from, and constant collaboration with, organizations representing diverse social groups. This will help to ensure that 
the work of psychologists can be applied to greatest effect for individuals and the community groups to which they belong.

It also worth considering how other indigenous peoples may learn from what has been achieved in Aotearoa/New Zealand. As a result of historical and social factors (for example, Te Tiriti o Waitangi and more recent human rights movements), Māori culture is seen as highly relevant in representations of New Zealand modern national identity, which is important both for affirming biculturalism and for promoting Aotearoa/New Zealand's positive distinctiveness as a nation. ${ }^{52}$ Although this is currently expressed more symbolically than pragmatically (that is, in equality of resource allocation), beliefs that Māori culture is relevant for the national identity may help achieve equal resources rights in the future. A similar trajectory of change may be possible for other indigenous peoples who are able to assert their right for strong symbolic recognition.

\section{Conclusion}

Although born in the unique context of Latin America, liberation psychology highlights important philosophical and practical issues that are of global relevance. It points out the subjectivity that is inherent in society's policies, institutions, and knowledge bases. In particular, it highlights how these societal fundamentals are dominated and controlled - however unintentionally - by powerful groups, at the great expense of marginalized communities. But liberation psychology does more than just reveal these awful truths; it also proposes a means of societal transformation, and prioritizes action and tangible social outcomes over words and theoretical refinements. As such, it presents a highly useful guiding framework for research, policy-making and service delivery in, with, and for, minority groups in countries such as Aotearoa/New Zealand.

Māori scholars have played, and will continue to play, an important role in 'liberating' or decolonizing the field of psychology in Aotearoa/New Zealand. Given the well-established influence and success of these scholars, and the considerable overlap in ideals and approaches between the kaupapa they have developed and the fundamentals of liberation psychology, some critics might question the need for liberation psychology to be introduced to Aotearoa/New Zealand as a 'new' approach. Certainly, it is not our intention to either eclipse or ignore the work that has already been done by Māori scholars, although regrettably we have had little room in this paper to explore their approaches in more detail. We are also aware of the dangers of presenting an approach as novel, when in fact it is well-established and worthy of greater support in its current form.

However, as we have attempted to illustrate in this paper, we believe that liberation psychology does offer something new and valuable for psychology 
in Aotearoa/New Zealand. In particular, it offers a connection to a broad, long-standing and internationally-relevant framework for understanding and tackling the ways in which mainstream approaches marginalize multiple groups, in both a historical and contemporary context. This framework may be particularly helpful and accessible for non-indigenous psychologists, who we believe have a responsibility to become aware of their own multi-layered cultural context and its inherent assumptions, and to consider the impacts of this context on their work in diverse Aotearoa/New Zealand communities.

It is our hope that this paper will provide a spring-board for future work in exploring what liberation psychology can offer in Aotearoa/New Zealand, including the development of applied initiatives that resonate with liberation psychology's underlying goal of achieving positive social change. We look forward to following the movement's progress, and perhaps even to seeing its lessons learned in Aotearoa/New Zealand being carried back to Latin America in the future.

1 The authors would like to thank Ruth Herd, Sue Crengle, James Liu, and Arama Rata for their insightful comments on an earlier draft of this paper. Portions of this paper were presented at the XXth Congress of the International Association of Cross-Cultural Psychology, Melbourne, Australia, July 2010.

2 P. Freire, Pedagogy of the Oppressed, New York, 1970; I. Martín-Baró, 'Hacia una psicología de la liberación [Towards a Psychology of Liberation]', Boletín de Psicología de El Salvador (BPES), 22 (1986), pp.219-31; I. Martín-Baró, Psicología de la liberación [Psychology of Liberation], Madrid, 1998.

3 M. Montero and C. Sonn, Psychology of Liberation, New York, 2010.

4 Martín-Baró spent most of his professional life working in El Salvador and at the Jose Simeon Cañas Central American University. He was the director of the academic journal Boletín de Psicología, and vice-president of the Interamerican Society of Psychology, a key antecedent of the International Association for Cross-Cultural Psychology (founded in 1972). He, along with other university colleagues, was assassinated by the Salvadoran Army on November 16, 1989.

5 Such an epistemology aligns liberation psychology with Freire's pedagogical approach by developing a psychology of the oppressed/oppression, and not a psychology for the oppressed. See Freire.

6 P. Berryman, Liberation Theology: Essential Facts about the Revolutionary Movement in Latin America and Beyond, London, 1987.

7 M. Burton, 'Viva Nacho! Liberating psychology in Latin America', Psychologist, 17, 10 (2004), pp.584-87; M. Burton and C. Kagan, 'Liberation social psychology: Learning from Latin America', Journal of Community and Applied Social Psychology (JCASP), 15 (2005), pp.63-78.

8 For a recent critique on this issue, see J. Henrich, S.J. Heine and A. Norenzayan, 'The Weirdest People in the World', Behavioral and Brain Sciences, 33 (2010), pp.61-83.

9 L. Comas-Díaz, M.B. Lykes and R.D. Alarcón, 'Ethnic Conflict and the Psychology of Liberation in Guatemala, PerFu, and Puerto Rico', American Psychologist, 53, 7 (1998), pp.778-92. 


\section{Journal of New Zealand Studies}

10 E. Duran, J. Firehammer and J. Gonzalez, 'Liberation Psychology as the Path Toward Healing Cultural Soul Wounds', Journal of Counselling \& Development, 86, 3 (2008), pp.88-95.

11 M. Montero, 'The Political Psychology of Liberation: From Politics to Ethics and Back', Political Psychology, 28, 5 (2007), pp.517-33.

12 S. M. Reich, T. Pinkard and H. Davidson, 'Including History in the Study of Psychological and Political Power', Journal of Community Psychology, 36, 2 (2008), pp.173-86.

13 Ibid.

14 See Duran, Firehammer and Gonzalez, pp.288-95; Martín-Baró, 'Hacia una psicología de la liberación'; and Montero, pp.517-33.

15 Burton, pp.584-87; Burton and Kagan, pp.63-78.

16 For a more detailed discussion, see E. Galeano, Open Veins of Latin America: Five Centuries of the Pillage of a Continent, Carlton North, Australia, 2009.

17 Comas-Díaz et al., pp.778-92.

18 In particular, the U.S. followed an interventionist attitude and policy to defend its interests in the region. This influence was often played out undemocratically - the documentary Condor (directed by Roberto Mader) provides some chilling examples, as does much of the writing of Noam Chomsky.

19 Burton and Kagan, pp.63-78.

20 Comas-Díaz et al., pp.778-92.

21 M.A. Gavarito, 'Aporte en Guatemala a la psicología social en la lucha contra la impunidad' [Guatemala's contribution to social psychology in the fight against impunity], June 2009. Paper presented at the 32nd Interamerican Congress of Psychology, Guatemala City, Guatemala.

22 Comas-Díaz et al., pp.778-92.

23 For readers unfamiliar with these terms, they denote modern, more accurate and less value-laden general descriptors of groups of countries that have high scores on indices such as gross domestic product per capita or the United Nations' Human Development Index (the minority or so-called 'developed' world), and countries that have lower scores on these indices (the majority world).

24 J.W. Berry, Y. Poortinga, M. Segall and P. Dasen, Cross-cultural Psychology: Research and Applications, Cambridge, 2002; N.K. Denzin, Y.S. Lincoln and L.T. Smith, Handbook of Critical and Indigenous Methodologies, Los Angeles, 2008; L.T. Smith, Decolonizing Methodologies: Research and Indigenous Peoples, London, 1999; L.T. Smith, 'On Tricky Ground: Researching the Native in the Age of Uncertainty', in N.K. Denzin and Y.S. Lincoln, eds., The SAGE Handbook of Qualitative Research, 3rd edition, Thousand Oaks, California, 2005, pp.85-107.

25 According to this 'Dark Duo' model of post-colonial ideology, indigenous peoples have experienced both objective historical injustice (thus engendering an ideology of Historical Recognition/Negation - that is, beliefs that historical injustices experienced by indigenous peoples in the colonial era are relevant/irrelevant in contemporary society) and have a claim of undeniable nationality (thus engendering an ideology of Symbolic Projection/ Exclusion - that is, beliefs that indigenous culture is relevant/irrelevant in representations of modern national identity). See C.G. Sibley, 'The Dark Duo of Post-Colonial Ideology: A Model of Symbolic Exclusion and Historical Negation', International Journal of Conflict and Violence (IJCV), 4 (2010), pp.106-23. 


\section{Liberation Psychology}

26 See, for example, World Bank, World Development Report 2006, Oxford, 2006.

27 See model developed by Sibley, 'Dark Duo', pp.106-23.

28 Burton and Kagan, pp.63-78.

29 See, for example, Berry, Poortinga, Segall and Dasen, ch. 17.

30 See Duran, Firehammer and Gonzalez, pp.288-95.

31 A.J. Norval, 'Memory, Identity and the (Im)possibility of Reconciliation: The Work of the Truth and Reconciliation Commission in South Africa', Constellations, 5 (1998), pp.250-65.

32 This apology 'acknowledged the legacy of trauma and grief in Aboriginal and Torres Islander communities as a result of colonisation, forced removals and other past government policies and, in doing so, marked the beginning of a new relationship between Aboriginal and Torres Strait Islander and non-Indigenous people, in which reconciliation and healing are possible'. See, Aboriginal and Torres Strait Islander Healing Foundation Development Team, Voices from the Campfires: Establishing the Aboriginal and Torres Strait Islander Healing Foundation, Canberra, 2009.

33 See, for example, R. Pepua, 'From Decolonizing Psychology to the Development of a Cross-Indigenous Perspective in Methodology: The Philippine Experience', in U. Kim, K.S. Yang and K.K. Hwang, eds., Indigenous and cultural psychology: Understanding people in context, New York, 2006, pp.109-37.

34 S. Kirkwood, J.H. Liu and A. Weatherall, 'Challenging the Standard Story of Indigenous Rights in Aotearoa/New Zealand', JCASP, 15 (2005), pp.493-505.

35 Ibid., p.495.

36 J.H. Liu and D.J. Hilton, 'How the Past Weighs on the Present: Social Representations of History and their Role in Identity Politics', British Journal of Social Psychology, 44 (2005), pp.537-56.

37 Burton and Kagan, pp.63-78.

38 G. Adams, L.T. O'Brien and J.C. Nelson, 'Perceptions of Racism in Hurricane Katrina: A Liberation Psychology Analysis', Analyses of Social Issues and Public Policy, 6, 1 (2006), pp.215-35.

39 A. Rata, J. Liu and K. Hanke, 'Te ara hohou rongo (the path to peace): Maori Conceptualisations of Inter-Group Forgiveness', Aotearoa/New Zealand Journal of Psychology (NZJP), 37, 2 (2008), pp.18-30.

40 Adams, O’Brien and Nelson, pp.215-35.

41 M. Durie, 'Mental Health and Maori Development', Australian and Aotearoa/New Zealand Journal of Psychiatry, 33, 1 (1999), pp.5-12; M. Durie, 'Understanding Health and Illness: Research at the Interface between Science and Indigenous Knowledge', International Journal of Epidemiology, 33 (2004), pp.1138-43.

42 Adams, O’Brien and Nelson, pp.215-35; C. Towns, N. Watkins, A. Salter, P. Boyd and L. Parkin, 'The Orewa Speech: Another Threat to Maori Health?', Journal of the Aotearoal New Zealand Medical Association, 117 (2004 Nov 5), p.U1145.

43 D. Ringold, 'New Frontiers of Social Policy' (Tanzania), 2005 (Conference Paper, Arusha Conference, December 12-15, 2005). http://siteresources.worldbank.org /INTRANETSOCIALDEVELOPMENT/Resources/RingoldMaori.rev.pdf, accessed 13 September 2009.

44 See Burton and Kagan, pp.63-78. 


\section{Journal of New Zealand Studies}

45 See Durie, 'Mental Health and Maori Development', pp.5-12; and Durie, 'Understanding Health and Illness', pp.1138-43.

46 M. Durie, Whaiora, Maori Health Development, Auckland, 1994.

47 T. Rochford, 'Whare tapa wha: A Maori Model of a Unified Theory of Health', The Journal of Primary Prevention, 25, 1 (2004), pp.41-57.

48 See, for example, Smith, Decolonizing Methodologies; Denzin and Lincoln, The SAGE Handbook of Qualitative Research, 3rd edition, pp.85-107.

49 S. Walker, A. Eketone and A. Gibbs, 'An Exploration of kaupapa Maori Research, its Principles, Processes and Applications', International Journal of Social Research Methodology, 9, 4 (2006), pp.331-44.

50 J.H. Liu and C.G. Sibley, 'Differential Effects of Societal Anchoring and Personal Importance in Determining Support or Opposition to (Bi)cultural Diversity in New Zealand', Papers on Social Representations, 15 (2006), pp.1-15; C.G. Sibley and J.H. Liu, 'New Zealand = Bicultural? Implicit and Explicit Associations between Ethnicity and Nationhood in the New Zealand Context', European Journal of Social Psychology, 37 (2007), pp.1222-43; C.G. Sibley, J.H. Liu and S.S. Khan, 'Who are 'we'? Implicit Associations between Ethnic and National Symbols for Maori and Pakeha in New Zealand', NZJP, 37 (2008), pp.38-49.

51 Perhaps indicating their intention to address these more difficult resource issues and strengthen their ongoing partnership with Māori, in April 2010 the government of Aotearoa/New Zealand formally endorsed the 2007 United Nations declaration on the rights of indigenous peoples. This document enshrines the land, resource, and human rights of indigenous peoples, and indicates each country's commitment to achieving equality for all its citizens.

52 See Liu and Sibley, 'Differential Effects', pp.1-15. 